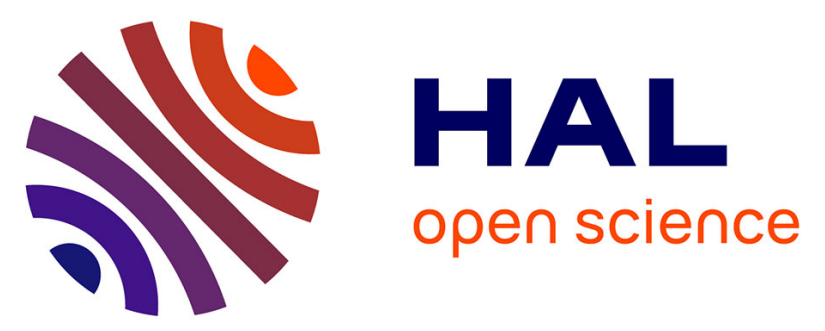

\title{
Monetary policy transmission in the euro area: New evidence from micro data on firms and banks
}

\author{
Jean-Bernard Chatelain, Andrea Generale, Philip Vermeulen, Michael \\ Ehrmann, Jorge Martínez-Pagés, Andreas Worms
}

\section{- To cite this version:}

Jean-Bernard Chatelain, Andrea Generale, Philip Vermeulen, Michael Ehrmann, Jorge MartínezPagés, et al.. Monetary policy transmission in the euro area: New evidence from micro data on firms and banks. Journal of the European Economic Association, 2003, 1 (2-3), pp.731-742. 10.1162/154247603322391350 . halshs-00119489v2

\section{HAL Id: halshs-00119489 \\ https://shs.hal.science/halshs-00119489v2}

Submitted on 11 Dec 2006

HAL is a multi-disciplinary open access archive for the deposit and dissemination of scientific research documents, whether they are published or not. The documents may come from teaching and research institutions in France or abroad, or from public or private research centers.
L'archive ouverte pluridisciplinaire HAL, est destinée au dépôt et à la diffusion de documents scientifiques de niveau recherche, publiés ou non, émanant des établissements d'enseignement et de recherche français ou étrangers, des laboratoires publics ou privés. 


\title{
MONETARY POLICY TRANSMISSION IN THE EURO AREA: NEW EVIDENCE FROM MICRO DATA ON FIRMS AND BANKS
}

\section{Jean-Bernard Chatelain}

Banque de France

LEO Université Orleans

Michael Ehrmann

European Central Bank

\section{Andrea Generale}

Banca d'Italia
Jorge Martínez-Pagés

Banco de España

Philip Vermeulen

European Central Bank

Andreas Worms

Deutsche Bundesbank

\begin{abstract}
This paper presents an overview of the results of a research project on monetary transmission pursued by the Eurosystem, which has analyzed micro data on firms and banks in several countries of the euro area in great detail. There is strong empirical support for an interest rate channel working through firm investment. Furthermore, a credit channel can be identified with firm micro data. On the bank side, there is evidence that lending reacts differently to monetary policy according to bank balance sheet characteristics. In particular, banks that have a less liquid asset composition show a stronger loan supply response. This finding may be due to banks drawing on their liquid assets to cushion the effects of monetary policy on their loan portfolio, which is in line with the existence of close relationships between banks and their loan customers. (JEL: C23, E52, G21)
\end{abstract}

\section{Introduction}

The European Monetary Union (EMU) constitutes a new currency area with a common monetary policy. To successfully conduct monetary policy in this new environment, it is of crucial importance to understand the monetary transmission process to the best possible extent. Since the member countries are characterized by marked differences both in the real and the financial sector, it is possible that the size as well as the dynamics of monetary policy effects differ among countries. These issues have recently been addressed in research projects in-

Acknowledgments: We would like to thank Simon Gilchrist and Nobuhiro Kiyotaki for their discussion at the EEA Congress, as well as the members of the Eurosystem's Monetary Transmission Network, and especially Ignazio Angeloni for constructive discussion and comments. This paper represents the authors' personal opinions and does not necessarily reflect the views of the institutions they are affiliated with.

E-mail addresses: Chatelain: jean-bernard.chatelain@wanadoo.fr; Ehrmann: michael.ehrmann@ ecb.int; Generale: generale.andrea@ insedia.interbusiness.it; Martínez-Pagés: martinezpages @ bde.es; Vermeulen: philip.vermeulen@ecb.int; Worms: andreas.worms@bundesbank.de. 
volving the European Central Bank (ECB) and the national central banks of the euro area (NCBs). ${ }^{1}$ This paper gives an overview of the microeconometric results (for the macroeconometric evidence see van Els et al. 2003, this volume).

Micro data can be usefully employed to gain a more in-depth understanding of monetary policy transmission and the possible relevance of heterogeneity. The research project used data on firms and on banks from several euro area countries, focusing mainly on two channels of monetary transmission. ${ }^{2}$ The first is the interest rate channel to firm investment via the cost of capital; the second is the credit channel, which relies on capital market imperfections due to informational asymmetries. Unlike the transmission through the interest rate channel, the existence of a credit channel implies that borrowers with a limited access to financial markets should be more responsive to changes in monetary conditions. This asymmetry exists if external finance premia-caused by the existence of information asymmetries - are affected by monetary policy to a different degree across economic agents: those that suffer more from information asymmetry problems experience a stronger increase of this premium following a monetary policy tightening. The credit channel theory distinguishes two subchannels that can cause such an asymmetric reaction: the balance sheet channel and the bank lending channel. ${ }^{3}$ The first one focuses on the effects monetary policy has on borrowers' (=firms') external finance premia by altering their balance sheets (especially the value of their collateral). The second regards the effects of monetary policy on the lenders' (=banks') balance sheets (especially the volume of deposits) and how this may influence their loan supply to nonbanks. It is based on the assumption that banks (which are themselves borrowers in the financial market, mainly from depositors) differ in their ability to raise alternative funds after a monetary tightening and that therefore also their loan supply will respond differently.

Both the interest rate and the credit channel can fruitfully be analyzed with micro data on firms: through the large cross-sectional dimension of the datasets analyzed, we expect to obtain more precise estimates of the cost of capital effects on investment than studies based on macro data. Moreover, since the credit channel predicts heterogeneous responses of firms, it can best be tested with disaggregated firm data.

Since in the euro area the bulk of financing to firms is supplied through banks, the behavior of the banking sector is potentially important for monetary

1. The projects were undertaken by the Eurosystem Monetary Transmission Network (MTN) and the Working Group of Econometric Modelling (WGEM). The former is a research network established in 1999 for conducting a comprehensive and in-depth study of the monetary policy transmission mechanism in the euro area based on both macro data and firm-level and bank-level micro data. The latter is a working group of modelling experts, which have assembled evidence on the transmission mechanism based on area-wide and national structural macro-models available in the Eurosystem. The full set of relevant papers is available as ECB Working Papers (numbers 91-114).

2. For an overview of these channels see Cecchetti (1995).

3. Bernanke and Gertler (1995). 
policy transmission. Therefore, the analysis has been extended to micro bank level data. These may help to assess whether the credit channel effects found with firm data could in principle be caused by the bank lending channel or if only the balance sheet channel is at work.

The results presented in this paper add to the literature in several dimensions. They are based on two empirical approaches. One consists of individual country analyzes with country-specific specifications. While this strategy has the advantage of describing monetary policy transmission in a given country to the best possible extent, it comes with the drawback that the heterogeneity in the model specifications does not allow for a direct comparability across countries. The other strategy therefore consists of applying a harmonized estimation approach for the four largest euro area countries in order to enable cross-country comparisons. The data sets that have been employed are of very high quality especially for banks, where they cover the full population, and had in many cases not been used for empirical analyses before.

In the next section, we present the model and econometric results for firm investment, analyzing the cost of capital effect as well as the credit channel. In Section 3, we report the model and the results for bank lending, where the analysis of the credit channel is complemented with evidence on bank behavior. Section 4 concludes.

\section{Firm Investment}

\subsection{Data and Model}

In this section, we report the results of several studies that analyze firm investment behavior to assess the relevance of the interest rate channel and the credit channel. The datasets used consist of firm balance sheet data available at the NCBs of the euro area. The coverage is generally quite large but differs across countries (see Table 2). The sample periods for which data are available vary from country to country-roughly, they cover the period from the mid1980 s to end of the 1990s.

The econometric model is derived from a standard neoclassical firm optimising framework following Chirinko, Fazzari and Meyer (1999), which leads to estimation equation (1):

$$
\frac{I_{i t}}{K_{i t-1}}=f_{i}+\sum_{j=1}^{l} b_{j} \frac{I_{i t-j}}{K_{i t-1-j}}+\sum_{j=0}^{m} c_{j} \Delta y_{i t-j}+\sum_{j=0}^{n} d_{j} \Delta u c_{i t-j}+\sum_{j=0}^{g} e_{j} \frac{C F_{i t-j}}{K_{i t-1-j}}+\varepsilon_{i t},
$$

with $i$ denoting individual firms and $t$ denoting time. $I / K$ represents the investment capital ratio, $\Delta y$ the sales growth rate, $\Delta u c$ the change in the user cost, and $C F / K$ the cash flow capital ratio. The model allows for fixed effects across firms, as indicated by the firm specific intercept $f_{i}$. Although alternative specifications 
of investment have been estimated in the literature, they usually perform less well empirically. Also, the forecasting performance of distributed lag models are found to be better (Oliner, Rudebusch and Sichel, 1995). In addition, the user cost elasticity is directly estimated in our model. The user cost is defined as the traditional Jorgensonian user cost including depreciation, interest rate terms and relative prices. ${ }^{4}$ Therefore, in case an interest channel is operative, the coefficients on the user cost changes should be significant and negative. The cash flow ratio enters as a measure of the availability of internal funds. It has been argued that the investment cash flow sensitivity could also capture expected profits, which e.g., determines investment in $q$ theory without financial constraints rather than effects of an external funds premium. Credit channel effects are therefore identified only by differences of the cash flow coefficients across firms under the assumption that there are no differences among groups of firms in the predictive power of cash flow for expected profits. ${ }^{5}$ The identifying assumption is that firms with a higher coefficient on cash flow suffer more from financial market imperfections. Since monetary policy affects cash flows, those firms are also likely to suffer more from monetary policy shocks. Sample comparisons using size as a discriminating characteristic of this liquidity condition of firms have been common in the empirical literature examining the link between financial constraints and investment.

Due to the inclusion of lags of the dependent variable, the models are estimated by GMM as suggested by Arellano and Bond (1991). This ensures efficiency and consistency of the estimates, provided that instruments are adequately chosen to take into account the serial correlation properties of the model (which is tested for with the standard Sargan test).

\subsection{Results}

Model (1) has been estimated in a harmonized fashion for the four largest countries of the euro area, France, Germany, Italy and Spain. These results are summarized in Table $1 .^{6} \mathrm{We}$ limit ourselves to reporting only the estimated long-run coefficients that represent the long run elasticity of the capital stock with respect to the regressors. ${ }^{7}$

The user cost has a significant long run effect on the capital stock in Germany and Italy (it is significant for Spain when nonsignificant lags are

4. For details see Chatelain et al. (2001), page 36.

5. Gilchrist and Himmelberg (1998) propose a method which allows to separate expectation effects from financial effects of cash flow.

6. See Chatelain et al. (2001).

7. The long run coefficients are calculated as the sum of the coefficients of the various lags of the indicated variable, divided by one minus the sum of the coefficients on the lagged endogenous variable. 
Table 1. Long-Run Coefficients Estimated in Model (1)

\begin{tabular}{lcccc}
\hline & France & Germany & Italy & Spain \\
\hline Sales & $0.12 * *$ & $0.39 * *$ & $0.14^{* *}$ & 0.02 \\
& $(0.05)$ & $(0.08)$ & $(0.05)$ & $(0.09)$ \\
User cost & -0.03 & $-0.52^{* *}$ & $-0.20^{* *}$ & -0.28 \\
& $(0.04)$ & $(0.15)$ & $(0.06)$ & $(0.20)$ \\
Cash flow & $0.20 * *$ & $0.08 * *$ & $0.30^{* *}$ & $0.15^{* *}$ \\
& $(0.04)$ & $(0.03)$ & $(0.03)$ & $(0.04)$ \\
\hline
\end{tabular}

Notes: ** denotes significance at the $5 \% / 1 \%$ level. Numbers in parentheses are standard errors.

excluded and for France when cash flow is dropped from the regression). This provides evidence for an operative interest rate channel in these countries. Cash flow is significant in all countries.

The results presented in Table 1 have been put to more detailed testing for France, Germany, and Italy, and similarly for other countries of the euro area in a set of companion papers. We provide a qualitative overview of their results in Table 2.

All studies find significant negative long run user cost elasticities, providing strong evidence for an operative interest channel in the whole euro area. Some studies test if different firm characteristics can explain differences in user cost sensitivity. Although no such characteristics can be identified for German and French firms, in the case of Italy small firms and firms with a high share of intangible assets have higher user cost elasticities. In Belgium, capital intensive industries are found to be more sensitive to the user cost. In Luxembourg, young firms are found to be more sensitive. These results indicate that one can expect

Table 2. Estimation Results of Firm Studies for Single Countries

\begin{tabular}{|c|c|c|c|c|}
\hline & \multicolumn{2}{|c|}{ Model specification } & \multicolumn{2}{|c|}{ Results: relevant firm characteristics } \\
\hline & $\begin{array}{l}\text { Sample } \\
\text { period }\end{array}$ & $\begin{array}{l}\text { No. of } \\
\text { obs }\end{array}$ & Highest user cost sensitivity & Highest liquidity sensitivity \\
\hline Austria & 1994-1999 & 2652 & - & $\begin{array}{l}\text { Firms with no close } \\
\text { relationship to a house } \\
\text { bank }\end{array}$ \\
\hline Belgium & $1986-1998$ & 157547 & Capital intensive industries & $\begin{array}{l}\text { Small services, } \\
\text { manufacturing }\end{array}$ \\
\hline France & $1986-1999$ & 61237 & - & $\begin{array}{l}\text { Equipment manufacturing, } \\
\text { firms with bad credit } \\
\text { rating }\end{array}$ \\
\hline Germany & $1988-1997$ & 44345 & - & Firms with bad credit rating \\
\hline Italy & 1984-1999 & 43912 & $\begin{array}{l}\text { Small firms, firms with } \\
\text { high share of intangible } \\
\text { assets }\end{array}$ & $\begin{array}{l}\text { Small firms, firms with high } \\
\text { share of intangible assets }\end{array}$ \\
\hline Luxembourg & $1992-1998$ & 517 & Young firms & Young firms \\
\hline
\end{tabular}


most firms in the euro area to react to interest rate changes, although not to the same extent.

Table 2 also provides an overview of the effect of liquidity on investment. ${ }^{8}$ No single criterion according to which firms are more sensitive to liquidity is found to be relevant in all countries. For example, size in itself does not seem to be sufficient to capture the presence of differences in external finance premia. However, all criteria that are relevant in individual countries point towards firms with less potential to provide adequate collateral. We take these differences of liquidity sensitivity to be indicative of potential credit channel effects. For instance, in both France and Germany, firms with a bad credit rating show a higher cash flow sensitivity. In Italy and Belgium, small firms are more sensitive to cash flow. Also, particular industries could be more vulnerable to credit channel effects. Small services firms in Belgium and equipment manufacturers in France are found to be more liquidity sensitive. For Austria, firms without a close relationship to a house bank show a higher liquidity sensitivity.

These results suggest that the interest rate channel is operative in the euro area. They do furthermore point to internal funds as a crucial determinant of firms' investment, with an effect that is stronger for those firms that are more likely to face financial constraints, so that the credit channel is also operative.

\section{Bank Lending}

\subsection{Data and Model}

The complementary studies of bank lending behavior use bank balance sheet data collected by the NCBs of the euro area that are available at least on a quarterly basis and cover the full population of banks in the respective countries. ${ }^{9}$ The sample periods for which data are available differ from country to country - they do roughly cover the 1990s, though, thus restricting the analysis in most cases to pre EMU (see Table 4 for details). Since bank-individual interest rates on loans are not available for all countries in a sufficient quality, the analysis focuses on loan quantities. The econometric model is a reduced form of a simple model of the loan and deposit market (for details see Ehrmann et al. 2001):

8. The Austrian and Luxembourg study did not use cash flow but the cash stock as their liquidity measure.

9. Prior research in this area (e.g., Favero, Giavazzi and Flabbi 1999; DeBondt 1999) has usually employed commercially compiled datasets like BankScope, which cover only a fraction of the banking population, at an annual frequency. Ehrmann et al. (2001) provide a comparative analysis, showing that these data cannot in general replicate the findings of the more comprehensive datasets. 


$$
\begin{aligned}
\Delta \log \left(L_{i t}\right)= & a_{i}+\sum_{j=1}^{l} b_{j} \Delta \log \left(L_{i t-j}\right)+\sum_{j=0}^{l} c_{j} \Delta r_{t-j}+\sum_{j=0}^{l} d_{j} \Delta \log \left(G D P_{t-j}\right) \\
& +\sum_{j=0}^{l} e_{j} i n f l_{t-j}+f x_{i t-1}+\sum_{j=0}^{l} g_{1 j} x_{i t-1} \Delta r_{t-j} \\
& +\sum_{j=0}^{l} g_{2 j} x_{i t-1} \Delta \log \left(G D P_{t-j}\right)+\sum_{j=0}^{l} g_{3 j} x_{i t-1} \text { infl } l_{t-j}+\varepsilon_{i t}
\end{aligned}
$$

where $L_{i t}$ are the loans of bank $i$ in quarter $t$ to the private non-financial sector, $\Delta r_{t}$ represents the first difference of a nominal short-term interest rate (used as measure of monetary policy), $\Delta \log \left(G D P_{t}\right)$ the growth rate of real GDP, and infl the inflation rate. The model allows for fixed effects across banks, as indicated by the bank specific intercept $a_{i}$.

$x_{i t}$ denotes a bank specific characteristic. Under the assumption that banks face a homogeneous loan demand with respect to $x_{i t}$, loan supply effects caused by monetary policy can be identified with equation (2) because the interaction of the bank specific characteristic with the changes in the interest rate singles out differential reactions of bank loan supply to monetary policy. ${ }^{10}$ The usual assumptions met in the bank lending channel literature are that a small, less liquid or less capitalized bank ${ }^{11}$ has more problems to offset monetary policy induced reductions in deposits. It should therefore react more strongly than a bank with a higher value of the respective bank characteristic. This would imply positive coefficients on the interaction terms. Size is measured by the log of total assets. Liquidity is defined as the ratio of liquid assets (cash, interbank lending and securities) to total assets, and capitalization is given by the ratio of capital and reserves to total assets. Model (2) is estimated with each of the bank characteristics in turn, as well as once with all three characteristics simultaneously. ${ }^{12}$ Since the results are qualitatively equivalent, we will only present and discuss those that are based on the simultaneous model in the subsequent section.

\subsection{Results}

Like model (1), model (2) is estimated using the GMM estimator suggested by Arellano and Bond (1991). The main results for France, Germany, Italy, and

10. For some countries, it has been possible to construct bank-specific demand proxies (e.g., Worms 2001). Since such an improvement in the control for demand did not affect the results, we are confident that the assumption of homogeneous loan demand with respect to $x_{i t}$ holds in general. However, see comments on the econometric results for Spain below.

11. For size, see e.g., Kashyap and Stein (1995), for liquidity, see, e.g., Kashyap and Stein (2000), and for capital, see, e.g., Peek and Rosengren (1995).

12. In this case, all possible combinations of the product of the bank characteristic variables are furthermore introduced. 
Table 3. Long-Run Coefficients Estimated in Model (2)

\begin{tabular}{lcccc}
\hline & France & Germany & Italy & Spain \\
\hline Monetary policy & $-1.97^{* *}$ & $-0.53^{* *}$ & $-0.83^{* *}$ & $-1.51^{* *}$ \\
& $(0.57)$ & $(0.20)$ & $(0.13)$ & $(0.43)$ \\
Real GDP & $2.98^{* *}$ & 0.08 & $1.39^{* *}$ & $1.70^{* *}$ \\
& $(0.37)$ & $(0.14)$ & $(0.21)$ & $(0.33)$ \\
Inflation & $-3.68^{* *}$ & $1.66^{* *}$ & -0.62 & $-2.07 * *$ \\
& $(0.51)$ & $(0.28)$ & $(0.39)$ & $(0.39)$ \\
Size $\cdot$ Monetary Policy & -0.06 & -0.04 & 0.08 & -0.21 \\
& $(0.22)$ & $(0.04)$ & $(0.05)$ & $(0.13)$ \\
Liquidity $\cdot$ Monetary Policy & $8.11^{* *}$ & $3.94^{* *}$ & $2.28^{* *}$ & $3.99 *$ \\
& $(1.93)$ & $(0.88)$ & $(0.83)$ & $(1.91)$ \\
Capitalization $\cdot$ Monetary Policy & 2.30 & -0.47 & 3.62 & -11.30 \\
& $(7.01)$ & $(5.34)$ & $(3.10)$ & $(9.11)$ \\
\hline
\end{tabular}

Notes: $* / * *$ denotes significance at the $5 \% / 1 \%$ level. Numbers in parentheses are standard errors.

Spain are summarized in Table 3. ${ }^{13}$ Again, we limit ourselves to reporting only the estimated long-run coefficients.

The long-run effects of a permanent increase in interest rates on loan growth of an average bank (shown in the first row of Table 3) are estimated to be negative in all countries, indicating that restrictive monetary policy reduces bank lending of the average bank. The reaction differs across countries, though: the smallest is found in Germany, the largest in France.

With respect to the interaction terms of bank characteristics with monetary policy, size does not emerge as a useful indicator for the distributional effects of monetary policy. It is insignificant in all countries. Also capitalization does not play an important role in distinguishing banks' reactions. However, liquidity seems to be important: more liquid banks reduce loans less in response to a restrictive monetary policy than less liquid banks do.

The results presented in Table 3 have been put to more detailed testing in a set of companion papers. Furthermore, there are several papers performing a similar analysis for other countries of the euro area. Since there is no single set of comparable parameter estimates from these papers, we provide a qualitative overview of their results in Table 4. For Spain, a more thorough analysis shows that the weakly significant effect of liquidity shown in Table 3 can be explained by differences in the composition of banks' loan portfolios. Furthermore, no liquidity effects can be detected when an alternative exogenous deposit-reducing shock is analyzed. For the other countries, the evidence of Table 3 is corroborated, however. Especially for the cases of Germany and Italy, several robustness checks confirm that liquidity is the dominant bank characteristic explaining lending reactions to monetary policy. The results for the other countries studied are strikingly similar. Size is significant only in Greece and the Netherlands. Portugal is the only case where loan supply effects are identified without liquidity as an important variable.

13. Taken from Ehrmann et al. (2001). 


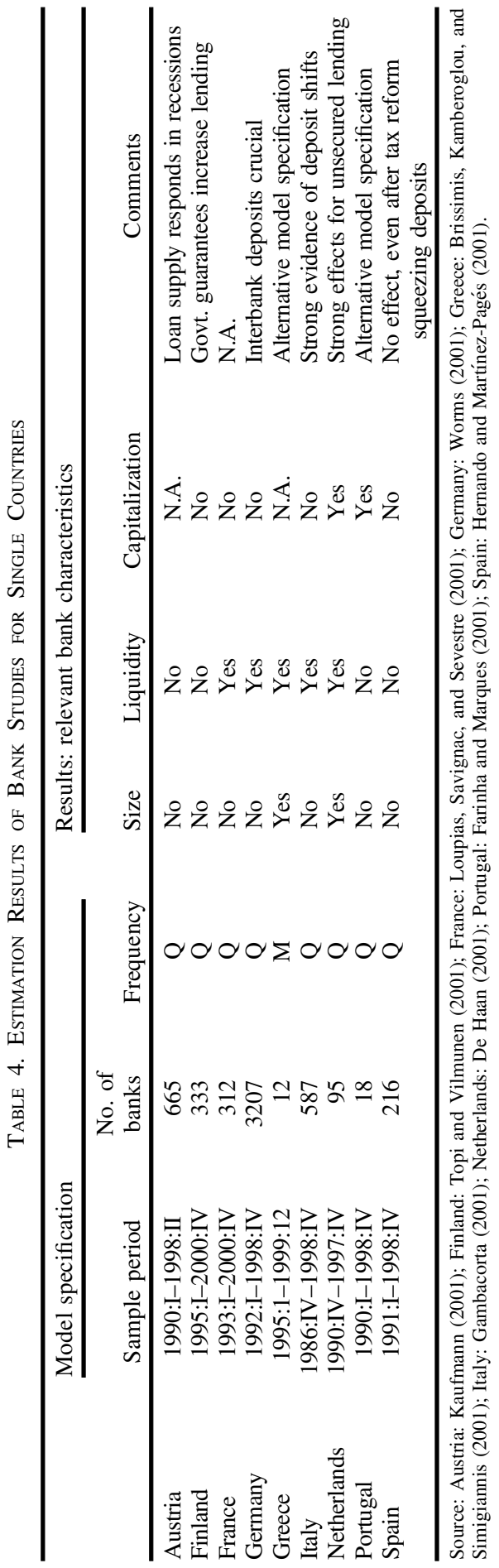


These results point to a crucial role of asset liquidity, and dismiss size as an important characteristic describing bank reaction to monetary policy. This is surprising, since size was found to be very important in the United States, where small banks restrict their lending by more than large banks after a monetary tightening. ${ }^{14}$ Several features of the euro area banking structure can help explain the different findings. ${ }^{15}$ First, historically, the perceived risk of investing in a small bank in the euro area may have been lower due to a higher government involvement and fewer bank failures. ${ }^{16}$ More importantly, in several countries, banks do not stand alone in the interbank market. Especially small banks are often organized in networks, which access the interbank market through their head institutions. Finally, there is evidence that some (usually small) banks, in several countries of the euro area, provide some kind of insurance to their clients by keeping strong liquidity positions on which they draw to shelter their clients from changes in monetary policy.

Ehrmann and Worms (2001) show that, in the context of bank networks, small banks "park" excess liquidity with the head institutions of their bank network in normal times, and use these liquid assets to maintain their loan portfolio following a monetary policy tightening. Worms (2001) shows that this intranetwork liquidity is the driving force for the dominant role of liquidity in the German case. This enables banks to draw on their liquid assets to cushion the effects of monetary policy on their loan portfolio, which is in line with the existence of close relationships between banks and their loan customers.

There is only very little evidence that capitalization influences the banks' lending reaction. This could be due to several reasons. For example, since the measure of capitalization we use is based on balance sheet data without taking into account the loan portfolio structure and its risk characteristics, it could be too crude to capture the riskiness of a bank, and is thus not indicative for the informational asymmetry problems. It might therefore not be capturing a riskbased measure such as the Basle capital requirement. ${ }^{17}$ Alternatively, it could of course be that capitalization is indeed not a significant determinant of a bank's reaction to monetary policy.

\section{Conclusions}

The empirical results summarized in this paper add up to a fairly consistent picture of monetary transmission in the euro area. First, the interest rate channel is operative for firm investment in the euro area. There is also evidence that

14. See e.g., Kashyap and Stein (1995).

15. A detailed analysis is provided in Ehrmann et al. (2001).

16. See LaPorta, Lopez-de-Silanes, and Shleifer (2002). Their data refer to 1995, which is contained in the econometric sample of most studies. In the meantime, government involvement has been reduced considerably in several countries of the euro area (see Ehrmann et al., 2001).

17. The BIS ratio measure can in most cases not be obtained from the available datasets. 
liquidity matters more for some groups of firms, namely those that are most likely to have limited collateral to pledge and to suffer relatively more from a monetary policy shock. However, no single firm characteristic, such as size, is sufficient to delineate those groups.

Regarding the evidence obtained with bank data, banks of different size do not react differently to monetary policy, which indicates that, due to institutional factors in the euro area, size may not be a good proxy for the degree of asymmetric information problems suffered by banks. Instead, their reaction to an increase in the short-term interest rate depends strongly on their degree of liquidity: less liquid banks reduce lending by more in response to a restrictive monetary policy action than more liquid banks do. This lends support to the hypothesis that banks typically draw on their liquid assets to cushion the effects of monetary policy on their loan portfolio, which is in line with the existence of close relationships between banks and their loan customers.

The analysis of firm investment and bank lending has shown that there is some evidence of an operative credit channel in the euro area. However, banks use liquidity to buffer the effects of monetary policy on lending. This squares with the results reported in this volume by van Els, Locarno, Mojon, and Morgan (2003), who identify a dominant role for the interest channel with macro data.

To gain a deeper understanding of the credit channel effects, it would be necessary to match data on borrowers and lenders. Unfortunately, this was impossible with the data available to us.

\section{References}

Arellano, M. and S. Bond (1991). "Some Tests of Specification for Panel Data: Monte Carlo Evidence and an Application to Employment Equations.” Review of Economic Studies, 58, pp. 277-297.

Bernanke, B. and M. Gertler (1995). "Inside the Black Box: The Credit Channel of Monetary Policy Transmission.” Journal of Economic Perspectives, 9, pp. 27-42.

Brissimis, S. N., N. C. Kamberoglou, and G. T. Simigiannis (2001). Is There a Bank Lending Channel of Monetary Policy in Greece? Evidence from Bank Level Data. ECB Working Paper No. 104.

Butzen, P., C. Fuss, and P. Vermeulen (2001). The Interest Rate and Credit Channel in Belgium: An Investigation with Micro-Level Firm Data. ECB Working Paper No. 107.

Cecchetti, S. (1995). "Distinguishing Theories of the Monetary Transmission Mechanism." Federal Reserve Bank of St. Louis Review, 77, pp. 83-97.

Chatelain, J.-B. and Andre Tiomo (2001). Investment, the Cost of Capital, and Monetary Policy in the Nineties in France: A Panel Data Investigation. ECB Working Paper No. 106.

Chatelain, J.-B., A. Generale, I. Hernando, U. von Kalckreuth, and P. Vermeulen (2001). Firm Investment and Monetary Transmission in the Euro Area. ECB Working Paper No. 112.

Chirinko, R. S., S. M. Fazzari, A. P. Meyer (1999). "How Responsive is Business Capital Formation to its User Cost? An Exploration with Micro Data." Journal of Public Economics, 74, pp. 53-80.

De Bondt, G. J. (1999). Banks and Monetary Transmission in Europe: Empirical Evidence. BNL Quarterly Review, 209, pp. 149-168. 
De Haan, L. (2001). The Credit Channel in the Netherlands: Evidence from Bank Balance Sheets. ECB Working Paper No. 98.

Ehrmann, M., L. Gambacorta, J. Martínez-Pagés, P. Sevestre, and A. Worms (2001). Financial Factors and the Role of Banks in Monetary Policy Transmission in the Euro Area. ECB Working Paper No. 105.

Ehrmann, M. and A. Worms (2001). Interbank Lending and Monetary Policy TransmissionEvidence for Germany, ECB WP No. 73.

Farinha, L. A. and C. R. Marques (2001). The Bank Lending Channel of Monetary Policy: Identification and Estimation Using Portuguese Micro Bank Data. ECB Working Paper No. 102.

Favero, C., F. Giavazzi, and L. Flabbi (1999). The Transmission Mechanism of Monetary Policy in Europe: Evidence from Banks' Balance Sheets. NBER Working Paper No. 7231. Gaiotti, E. and A. Generale (2001). Does Monetary Policy Have Asymmetric Effects? A Look at the Investment Decisions of Italian Firms. ECB Working Paper No. 110.

Gambacorta, L. (2001). Bank Specific Characteristics and Monetary Policy Transmission: The Case of Italy. ECB Working Paper No. 103.

Gilchrist, S. and C. Himmelberg (1998). "Investment, Fundamentals and Finance." NBER Macroeconomics Annual 1998, pp. 223-262.

Hernando, I. and J. Martínez-Pagés (2001). Is There a Bank Lending Channel of Monetary Policy in Spain? ECB Working Paper No. 99.

Kashyap, A. and J. Stein (1995). "The Impact of Monetary Policy on Bank Balance Sheets." Carnegie Rochester Conference Series on Public Policy, 42, pp. 151-195.

Kashyap, A. and J. Stein (2000). "What do a Million Observations on Banks Say about the Transmission of Monetary Policy." American Economic Review, 90, pp. 407-428.

Kaufmann, S. (2001). Asymmetries in Bank Lending Behaviour. Austria During the 90s. ECB Working Paper No. 97.

La Porta, R., F. Lopez-de-Silanes, and A. Shleifer (2002). "Government Ownership of Banks." Journal of Finance, LVII, (1), pp. 265-301.

Loupias, C., F. Savignac, and P. Sevestre (2001). Monetary Policy and Bank Lending in France. Are There Asymmetries? ECB Working Paper No. 101.

Lünnemann, P. and T. Mathä (2001). Monetary Transmission: Empirical Evidence from Luxembourg Firm Level Data. ECB Working Paper No. 111.

Oliner, S., G. Rudebusch, and D. Sichel (1995). "New and Old Models of Business Investment: A Comparison of Forecasting Performance." Journal of Money, Credit and Banking, 27, pp. 806-826.

Peek, J. and E. S. Rosengren (1995). "Bank Lending and the Transmission of Monetary Policy." In Is Bank Lending Important for the Transmission of Monetary Policy? Federal Reserve Bank of Boston Conference Series 39, edited by J. Peck and E. S. Rosengren.

Topi, J. and J. Vilmunen (2001). Transmission of Monetary Policy Shocks in Finland; Evidence from Bank Level Data on Loans. ECB Working Paper No. 100.

Valderrama, M. (2001). Credit Channel and Investment Behaviour in Austria: A MicroEconometric Approach. ECB Working Paper No. 108.

van Els, P., A. Locarno, B. Mojon, and J. Morgan (2003). "New Macroeconomic Evidence on Monetary Policy Transmission in the Euro Area," Journal of the European Economic Association, 1(2-3), pp. 720-730.

von Kalckreuth, U. (2001). Monetary Transmission in Germany: New Perspectives on Financial Constraints and Investment Spending. ECB Working Paper No. 109.

Worms, A. (2001). The Reaction of Bank Lending to Monetary Policy Measures in Germany. ECB Working Paper No. 96. 